\title{
Massive Inguinoscrotal Bladder Hernia and Bladder Tumor: A Very Rare Case
}

\author{
Masif Inguinoskrotal Mesane Hernisi ve Mesane Tümörü: Çok Nadir Bir Olgu
}

\author{
(1) Oktay Özman, (1) Uğur Aferin, (1) Sinharib Çitgez, (1) Çetin Demirdağ, (1) Zübeyr Talat \\ İstanbul University Cerrahpaşa Faculty of Medicine, Department of Urology, Istanbul, Turkiye
}

\begin{abstract}
Here, we present a case of a 60-year-old male patient with inguinoscrotal bladder hernia and a bladder tumor who underwent cystoscopy and had no transurethral access. On the images, a massive inguinoscrotal hernia and a mass of $2.8 \mathrm{~cm}$ in diameter in the bladder were seen. First of all, hernia was repaired. Transurethral resection of the tumor was then performed. The tumor was in the posterior wall. High-grade T2 urothelial carcinoma was detected. The patient was offered radical surgery but he refused the operation. Multimodal therapy was recommended for the patient.

Keywords: Bladder, Bladder tumor, Urinary bladder, Prolapse
\end{abstract}

\section{Öz}

Bu raporda 60 yaşında inguinoskrotal mesane hernisi ve mesane tümörü olan, sistoskopi için başarısız üretral akses öyküsü olan bir erkek hasta sunulmaktadır. Görüntülemelerde masif bir inguinoskrotal herni ve 2,8 cm çapında mesane tümörü saptandı. Öncelikle herni tamiri yapıldı ve ardından tümör transüretral olarak rezeke edildi. Tümör posterior duvardaydı. T2 mesane kanseri saptanan hastaya radikal cerrahi önerildi fakat hasta tedaviyi reddetti. Bunun üzerine hastaya multimodal tedavi önerildi.

Anahtar Kelimeler: Mesane, Mesane tümörü, İdrar kesesi, Prolapsus

\section{Introduction}

Inguinoscrotal bladder hernia is a very rare condition (1). It usually causes scrotal swelling and lower urinary tract symptoms. In symptomatic patients, spontaneous urination following manual pressure over the hernia sac is typical of two-phase voiding (2). Most of the patients are male and the hernia is right-sided. Previous studies have reported that it was common in men aged 50-70 years (3). There is often a slight herniation towards the inguinal canal. Massive hernias in which the bladder is completely located in the scrotum are much less common. Treatment is surgical repair of the hernia.

Cases in which tumors are detected in the herniated bladder are very rare. In the literature, only 15 cases of malignancy originating from the herniated bladder have been reported. We present the case of a 60-year-old male patient who underwent cystoscopy for hematuria and had no transurethral access.

\section{Case Presentation}

A 60-year-old male patient was admitted to our clinic with scrotal swelling and intermittent hematuria. Scrotal swelling was present for 3 years and hematuria for 1 year. Cystoscopy was intended to be performed in the external center, but transurethral access was not achieved. Blood tests were normal and the kidney function was not impaired. The patient had no irritative or obstructive lower urinary tract symptoms. However, the patient was describing a two-phase voiding. The uroflowmetry test was normal $\left(0_{\max }: 16 \mathrm{~mL} / \mathrm{sec}\right)$. Repeated measurements with transabdominal and transscrotal bladder scans did not detect residual urine after voiding. Residual urine control was also performed with a urethral catheter. The prostate could not be palpated by digital rectal examination. The urine culture was sterile and the prostate-specific antigen value was normal $(0.476 \mathrm{ng} / \mathrm{mL})$. An advanced inguinoscrotal vesical hernia was seen on abdominopelvic computed tomography (CT).

Correspondence: Oktay Özman MD, İstanbul University Cerrahpaşa Faculty of Medicine, Department of Urology, İstanbul, Turkiye

Phone: +90 2124143000 E-mail: ozmanoktay@hotmail.com ORCID-ID: orcid.org/0000-0003-2499-8947

Received: 27.09.2017 Accepted: 15.11.2017

Cite this article as: Özman 0, Aferin U, Çitgez S, Demirdağ Ç, Talat Z. Massive Inguinoscrotal Bladder Hernia and Bladder Tumor: A Very Rare Case. J Urol Surg 2018;5(4):202-204.

${ }^{\circ}$ Copyright 2018 by the Association of Urological Surgery / Journal of Urological Surgery published by Galenos Publishing House. 
The bladder was completely in the scrotal sac (Figure 1). The distal parts of the bilateral ureters and the prostate were seen to be pulled toward the inguinal canal (Figure 2). In addition, a $1.4 \mathrm{~cm}$ lesion on the lateral side of the right adrenal gland was observed on CT scan. There were several millimetric calculations and multiple cysts in both kidneys. A mass of $2.8 \mathrm{~cm}$ in diameter extending from the wall to lumen was seen in the bladder located in the scrotum. First, the bladder hernia was repaired. Transurethral resection of the tumor was then performed. It was determined that the bilateral kidneys were free of stones in the patient who had stone dropping after repair of the hernia. The pathology of the bladder tumor was reported as high grade T2 urothelial carcinoma. Radical cystectomy + urinary diversion were recommended for the patient. However, the patient refused the operation, stating that his complaints had receded after the repair. The tumor was located in the posterior wall of

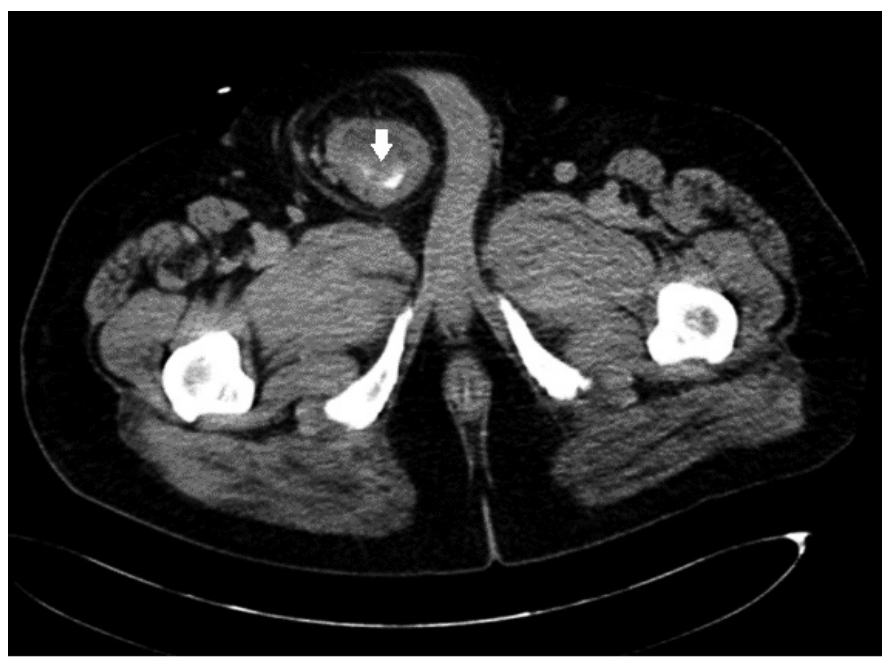

Figure 1. Hyperdense bladder tumor in the herniated bladder

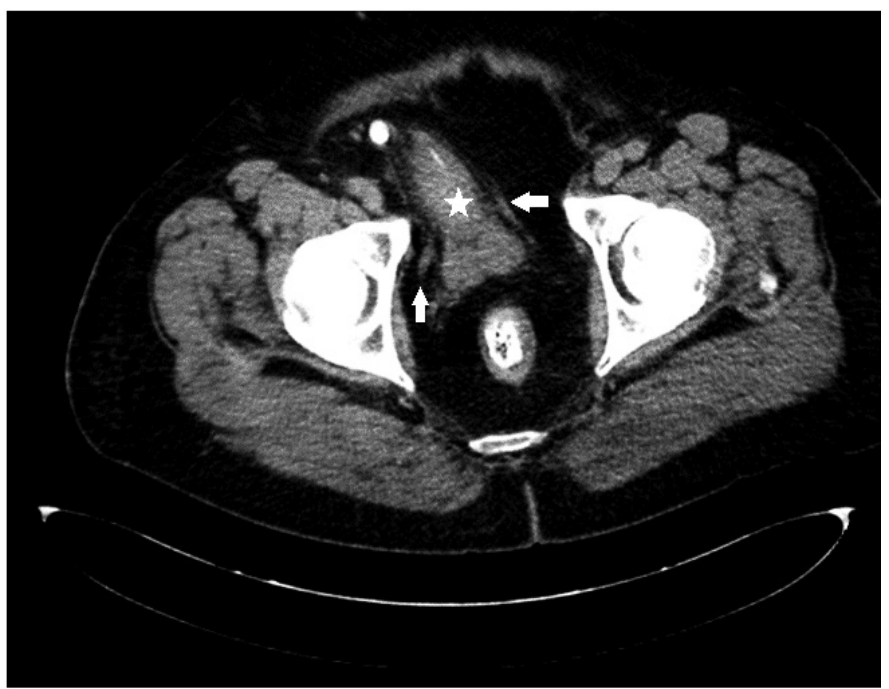

Figure 2. Herniated bladder accompanied by bladder neck and bilateral ureters the bladder. Since partial cystectomy was not an option, the patient was then offered multimodal therapy.

All procedures performed in studies involving human participants were in accordance with the ethical standards of the institutional research committee and with the 1964 Helsinki Declaration and its later amendments or comparable ethical standards.

Patient's approval was taken.

\section{Discussion}

Various studies have reported that $1-3 \%$ of inguinal hernias were associated with herniation of the bladder (4). As it can be understood, most of the bladder hernias are mild hernias limited to the inguinal canal. Advanced cases, where the entire bladder is placed in the scrotum, is rather rare.

Most cases are asymptomatic and diagnosed perioperatively (3). Some of them are diagnosed after the occurrence of postoperative complications. Very few are diagnosed with assessments of the symptoms. In our case, there were the complaints of scrotal swelling and hematuria related to the bladder tumor.

Hernia is evaluated in three groups according to its relationship with the peritoneum (5). Paraperitoneal hernias, where the outer part of the herniated bladder is wrapped with the peritoneum, are the most frequent group. Hernias that are all covered with the peritoneum are called intraperitoneal hernia. Hernias unrelated to the peritoneum are defined as extraperitoneal. Our case was classified as extraperitoneal hernia at perioperative evaluation.

Common etiologies of bladder hernia include obesity, pelvic wall failure, and bladder outlet obstruction (6). No evidence of other etiologies was found in the patient whose body mass index was $32 \mathrm{~kg} / \mathrm{m}^{2}$. Most of the cases reported in the literature were asymptomatic. In our case, the patient was admitted due to macroscopic hematuria. In addition, other common symptoms, such as two-phase voiding and scrotal swelling, were also detected.

Bladder diverticulum, mesenteric cyst hernia, hydrocele and spermatic cord cyst should be considered in the differential diagnosis (6). On ultrasonography, mild hydrocele in the right testis was observed. Hydrocele was thought to be due to bladder hernia, the ureters pulled toward the inguinal canal and cord pressure caused by the prostate.

Oruç et al. (7) reported that $11.2 \%$ of 190 cases of inguinal hernia were associated with urological malignancy. The association of a massive inguinoscrotal bladder hernia and bladder tumor is very 


\begin{tabular}{lll}
\hline \multicolumn{3}{l}{ Table 1. Previously reported case reports } \\
\hline Author & Year & Number of patients \\
\hline Oppenheimer & 1943 & 1 \\
Marcus & 1953 & 1 \\
Elliott & 1972 & 1 \\
Tasca et al. & 1978 & 1 \\
Lasaponara et al. & 1979 & 1 \\
Epner et al. (4) & 1993 & 1 \\
Pardo Garcia et al. (8) & 1997 & 1 \\
Dario Casas et al. & 1997 & 1 \\
Pareira Arias et al. & 1998 & 1 \\
Caterino et al. & 2001 & 1 \\
Oruç et al. (7) & 2004 & 1 \\
Das et al. & 2007 & 1 \\
Pastor Navarro et al. & 2010 & 2 \\
Katsourakis et al. (6) & 2014 & 1 \\
\hline
\end{tabular}

rare (Table 1). In fact, this patient, who also had mild hydrocele, benign adrenal mass, bilateral renal cyst and stones, is a unique case that has not been reported in the literature before.

The main aims of the treatment are repair of the bladder hernia and endoscopic diagnosis and treatment of the tumor (6). However, there may be differences between the approaches of physicians. In 1993, Epner et al. (4) performed partial cystectomy for a tumor in a herniated bladder. In a case reported by Pardo Garcia et al. (8), bladder perforation and scrotal abscess occurred.

Massive inguinoscrotal bladder hernia is a very rare condition. Its association with bladder tumor has been reported less frequently. The main purpose of the treatment should be endoscopic diagnosis and treatment of the tumor.

\section{Ethics}

Informed Consent: Patient's approval was taken.

Peer-review: Externally peer-reviewed.

\section{Authorship Contributions}

Surgical and Medical Practices: 0.Ö., C..D., Z.T., Concept: 0.Ö., Design: Ç.D., Data Collection or Processing: 0.0̈., U.A., Analysis or Interpretation: 0.0̈., S.Ç., Literature Search: 0.0̈., Writing: 0.0̈., Ç.D.

Conflict of Interest: No conflict of interest was declared by the authors.

Financial Disclosure: The authors declared that this study received no financial support.

\section{References}

1. Bisharat M, O'Donnell ME, Thompson T, MacKenzie N, Kirkpatrick D, Spence RA, Lee J. Complications of inguinoscrotal bladder hernias: a case series. Hernia 2009;13:81-84.

2. Kraft KH, Sweeney S, Fink AS, Ritenour CW, Issa MM. Inguinoscrotal bladder hernias: report of a series and review of the literature. Can Urol Assoc $J$ 2008;2:619-623.

3. Kim KH, Kim MU, Jeong WJ, Lee YS, Kim KH, Park KK, Chung MS, Chung BH, Lee SH. Incidentally Detected Inguinoscrotal Bladder Hernia. Korean J Urol 2011;52:71-73.

4. Epner SL, Rozenblit A, Gentile R. Direct inguinal hernia containing bladder carcinoma: CT demonstration. AJR Am J Roentgenol 1993;161:97-98.

5. Gomella LG, Spires SM, Burton JM, Ram MD, Flanigan RC. The surgical implications of herniation of the urinary bladder. Arch Surg 1985;120:964967.

6. Katsourakis A, Noussios G, Svoronos C, Alatsakis M, Chatzitheoklitos E. Direct inguinal hernia containing bladder carcinoma: A case report and review of the literature. Int J Surg Case Rep 2014;5:180-182.

7. Oruç MT, Akbulut Z, Özozan Ö, Coşkun F. Urological findings in inguinal hernias: A case report and review of the literature. Hernia 2004;8:76-79.

8. Pardo Garcia JL, Perez Calvo J, Domingo Garcia P, Carrasco Gonzalez L, Gonzalez Pina B, Murcia Valcarcel A. [Occult bladder cancer in incarcerated inguinal hernia. Report of a case and review of the literature]. Arch Esp Urol 1997;50:1007-1009. 